UTILITY: Jurnal IImiah Pendidikan dan Ekonomi

Volume 5, No. 1, Februari 2021: Page 10-15

ISSN 2549-1377 (Print) || ISSN 2549-1385 (Online)

Available online at $h$ ttp://journal.stkipnurulhuda.ac.id/index.php/utility

\title{
PENGARUH SANKSI PAJAK SERTA PENGETAHUAN MASYARAKAT TENTANG PAJAK TERHADAP KEPATUHAN MEMBAYAR WAJIB PAJAK
}

\author{
Debyta Ayu Umi Hani ${ }^{1}$, Imahda Khori Furqon ${ }^{2}$ \\ ${ }^{1,2}$ Program Studi Perbankan Syariah, Fakultas Ekonomi Bisnis Islam \\ *E-mail: debitaayu1701@gmail.com
}

\begin{abstract}
Abstrak: Pajak merupakan sumber utama Negara dalam mendanai belanja Negara. Pajak adalah kontribusi wajib kepada Negara yang terutang oleh orang pribadi atau badan yang bersifat memaksa berdasarkan undang-undang, dengan tidak mendapatkan imbalan secara langsung dan digunakan untuk keperluan Negara untuk kemakmuran rakyat Tujuan dari penelitian ini yaitu untuk menguji pengaruh sanksi pajak serta pengetahuan masyarakat tentang pajak terhadap kepatuhan membayar wajib pajak.Kepatuhan pajak jadi permasalahan yang belum terselesaikan saat ini di Indonesia, karena pada dasarnya karakteristik perilaku wajib pajak yang menyebabkan rendahnya kepatuhan pajak yaitu ketidakpatuhan yang disebabkan oleh ketidaktahuab dan ketidakpatuhan yang disengaja. Metode yang digunakan dalam penelitian ini yaitu menggunakan metode kualitatif.
\end{abstract}

Kata Kunci: Sanksi Pajak, Pengetahuan Pajak, Kepatuhan Pajak

\section{PENDAHULUAN}

Di era sekarang, kesadaran masyarakat terhadap wajib pajak sangatlah rendah.Sebagai Negara berkembang memerlukan pembiayaan belanja Negara yang semakin lama semakin bertambah besar. Saat ini pemerintah sedang berusaha meningkatkan sumber pembiayaan Negara, salah satu pembiayaan tersebut yaitu pembiayaan pajak.Penerimaan pajak secara tidak langsung bertujuan meningkatkan kemakmuran dan kesejahteraan masyarakat.Pajak merupakan sumber utama Negara dalam mendanai belanja Negara.Pajak merupakan iuran wajib bagi rakyat yang diberikan kepada Negara, bersifat memaksa dan tidak memperoleh imbalan secara lamgsung.Tanpa pajak sebagian besar kegiatan pusat dan daerah sulit untuk dilaksanakan.

Dilansir dari laman Kementrian Keuangan (Kemenkue), APBN 2020 pada penerimaan pajak mencapai Rp.279,89 triliun, meningkat 0.43 persen. Penerimaan pajak diharapkan terus meningkat agar pembangunan Negara dapat berjalan dengan baik bagi kehidupan ekonomi masyarakat.

Kepatuhan pajak jadi permasalahan yang belum terselesaikan saat ini di Indonesia, karena pada dasarnya karakteristik perilaku wajib pajak yang menyebabkan rendahnya kepatuhan pajak yaitu ketidakpatuhan yang disebabkan oleh ketidaktahuan dan ketidakpatuhan yang disengaja. Ketidaktahuan wajib pajak terkait dengan pemenuhan hak dan kewajiban perpajakan seperti menghitung 


\section{Pengaruh Sanksi Pajak Serta Pengetahuan Masyarakat Tentang Pajak Terhadap Kepatuhan Membayar Wajib Pajak}

besaran pajak terutang menyebabkan wajib pajak tidak membayarkan wajib pajak tidak membayar pajak serta melaporkan Surat Pemberitahuan (SPT) yang seharusnya menjad kewajiban yang harus dipenuhi. Sedangkan ketidakpatuhan yang disengaja adalah salahsatu bentuk perilaku yang dengan sadar berusaha untuk menghindari pajak seperti mengecilkan omset agar pajak yang dibayarkan menjadi lebih kecil.

Masalah kepatuhan pajak telah menjadi fenomena yang sering terjadi baik Negara maju maupun berkembang.Kepatuhan pajak dapat diartikan sebagai sejauh mana wajib pajak dapat mematuhi aturan pajak yang telah ditetapkan. Faktor-faktor yang dapat mempengaruhi tingkat kepatuhan wajib pajak yaitu : (a) sosialisasi pajak yang merupakan salah satu cara yang dilakukan oleh DJP dalam memberikan pengertian informasi, dan pembinaan kepada wajib pajak tentang segala sesuatu yang berhubungan dengan peraturan Per UU. (b) kesadaran wajib pajak yang merupakan bentuk kesungguhan yang dimiliki wajib pajak dengan timbulnya keinginan untuk patuh dalam membayar dengan melaporkan pajak. (c) sanksi perpajakan yang merupakan peraturan perundang-undangan (norma perpajakan) akan dituruti/ditaati/dipatuhi dengan kata lain sanksi perpajakan merupakan alat pencegahan bagi wajib pajak agar tidak melanggar norma perpajakan.

Berdasarkan latar belakang yang telah dijabarkan di atas, maka dapat diambil rumusan masalah sebagai berikut : (1) apakah pengetahuan masyarakat tentang wajib pajak dapat mempengaruhi kepatuhan membayar wajib pajak?; (2) apakah dengan adanya sanksi pajak dapat mempengaruhi kepatuhan masyarakat dalam membayar pajak?. maka dari rumusan masalah tersebut tujuan dari penelitian ini adalah untuk menguji "Pengaruh Sanksi Pajak serta Pengetahuan Masyarakat Tentang Pajak Terhadap Kepatuhan Membayar Wajib Pajak"

\section{HASIL DAN PEMBAHASAN}

\section{Pengertian Pajak}

Pajak merupakan peralihan kekayaan dari pihak rakyat kepada kas Negara untuk membiayai pengeluaran rutin dan surplus yang digunakan untuk kepentingan publik saving yang merupakan sumber utama untuk membiayai public investment. Dilansir dari laman DJP (Direktorat Jenderal Pajak), pajak adalah kontribusi wajib kepada Negara yang terutang oleh orang pribadi atau badan yang bersifat memaksa berdasarkan undang-undang, dengan tidak mendapatkan imbalan secara langsung dan digunakan untuk keperluan Negara untuk kemakmuran rakyat.

\section{Wajib Pajak (WP) \\ Wajib pajak merupakan orang pribadi atau badan mencangkup pembayaran atau pemotongan pajak dalam melakukan hak dan kewajiban perpajakan berdasarkan undang-undang perpajakan menurut Undang-undang nomor 16 Tahun 2000 tentang ketentuan umum dan tata cara perpajakan. Wajib pajak merupakan orang pribadi atau badan yang mnurut ketentuan peraturan perundang-undangan perpajakan ditentukan untuk melakukan kewajiban perpajakan termasuk pemungut pajak atau pemotongan pajak tertentu. Wajib pajak terbagi menjadi tiga, antara lain ; wajib pajak badan, wajib pajak orang pribadi, dan badan usaha tetap (BUT). Wajib}


Pajak Orang Pribadi (WPOP) merupakan seseorang yang mempunyai penghasilan kena pajak (neto) dalam satu tahun pajak yang jumlahnya di atas penghasilan tidak kena pajak (PTKP).

\section{Sanksi Perpajakan}

Sanksi merupakan hukuman kepada orang yang tidak taat pada peraturan, sanksi dibuat agar wajib pajak melakukan hak dan kewajibannya sesuai Undang-undang yang berlaku. Menurut Sari (2013) dalam Aprillia Citra Utami (2020) terdapat dua sanksi perpajakan antara lain :

1. Sanksi Administrasi

a. Sanksi administrasi berupa denda

Besarnya sanksi administrasi berupa denda ini ditetapkan dengan jumlah, presentase, atau suatu angka perkalian dan jumlah tertentu. Pada pelanggaran tertentu misalnya tidak melakukan pelaporan SPT, sanksi administrasi berupa denda ini akan ditambah dengan sanksi pidana dengan pelanggaran yang sifatnya disengaja.

b. Sanksi administrasi berupa bunga

Sanksi administrasi berupa bunga ini dikenakan atas pelanggaran yang menyebabkan utang pajak menjadi lebih besar. Jumlah bunga akan dihitung berdasarkan presentase tertentu dari suatu jumlah, dimulai dari bunga itu menjadi hak kewajiban sampai dengan saat diterima dibayarkan.

c. Sanksi administrasi berupa kenaikan

Sanksi administrasi berupa kenaikan ini pada dasarnya dihitung dengan angka presentase tertentu dari jumlah pajak yang dalam ini bukan termasuk pada kategori kurang bayar. Penyebab adanya sanksi administrasi berupa kenaikan ini karena wajib pajak tidak memberikan informasi yang diperlukan dalam penghitungan pajak terhutang.

\section{Sanksi Pidana}

Sanksi pidana ini merupakan langkah terakhir untuk meningkatkan kepatuhan wajib pajak.Sanksi pidana ini dapat berupa pidana kurungan dan pidana penjara sesuai dengan berat ringannya pelanggaran yang dilakukan wajib pajak.

Berdasarkan UU KUP tahun 2007 pasal 7 ayat 1, sanksi administrasi berupa denda digunakan untuk wajib pajak orang pribadi yang tidak melaporkan SPT, yaitu denda sebesar Rp. 100.000 bagi SPT PPh wajib pajak orang pribadi.

\section{Pengetahuan Perpajakan}

Pengetahuan perpajakan adalah kemampuan seorang wajib pajak dalam mengetahui peraturan perpajakan baik itu soal tarif pajak berdasarkan undang-undang yang akan mereka bayar maupun manfaat pajak yang akan berguna bagi kehidupan mereka (Noviyanti dan Effendi, 2014) dalam (Popy dan Rachmawati, 2020).

\section{Kepatuhan Perpajakan}

Menurut (Restu, 2014) dalam jurnal (Venichia Qibtisari Nugroho, 2020) kepatuhan wajib pajak didefinisikan sebagai tindakan perilaku dari seorang wajib pajak dalam melakukan semua kewajiban perpajakan dan menggunakan hak perpajakannya 


\section{Pengaruh Sanksi Pajak Serta Pengetahuan Masyarakat Tentang Pajak Terhadap Kepatuhan Membayar Wajib Pajak}

berdasarkan kepada peraturan perundang-undangan perpajakan yang telah berlaku. Tingkat kepatuhan wajib pajak apabila mengalami penurunan menjadi sangat penting karena ketidakpatuhan perpajakan akan memunculkan upaya penghindaraan dan penggelapan pajak, yang secara tidak langsung dapat menyebabkan penurunan penerimaan pajak pada kas negara Indonesia. Kepatuhan wajib pajak sebagai pemenuhan kewajiban perpajakan berdasarkan persepsi wajib pajak atas kewajaran dalam memahami, merasakan dan berperilaku terhadap makna dan fungsi pajak.Kepatuhan wajib pajak dibagi menjadi dua macam yaitu kepatuhan formal dan kepatuhan marerial. Kepatuhan formal merupakan suatu bentuk dimana wajib pajak memenuhi kewajiban secara formal/legal berdasarkan pada Undang-Undang perpajakan. Kepatuhan material merupakan suatu bentuk dimana wajib pajak secara subtantif/hakikatnya memenuhi semua ketentuan material perpajakan bedasarkan isi dan jiwa Undang-Undang pajak.Kepatuhan material juga bagian dari kepatuhan formal.

\section{Pengaruh Sanksi Pajak Terhadap Kepatuhan Wajib Pajak}

Penerapan sanksi dalam perpajakan penting karena menjadi akibat tidak terpenuhinyakewajiban perpajakan yang telah ditetapkan dalam undang-undang perpajakan. Dilihat dariaspek penegak hukum, harus diterapkannya sanksi yang tegas dan adil kepada setiap wajibpajak yang melanggar aturan perpajakan, penerapan sanksi tersebut diharapkan mampumembuat para wajib pajak lebih patuh dalan membayar pajak (Savitri dan Nuraina, 2017)dalam .Pada penelitian yang mengungkapkan bahwa salah satu faktor yang berpengaruh terhadapkepatuhan wajib pajak adalah sanksi pajak. Sanksi akan dijatuhkan atau dikenakan jikawajib pajak tidak mematuhi peraturan perpajakan yang telah dibuat oleh pemerintah (Victor,2018). Hasil penelitian tersebut juga didukung oleh penelitianyang mengatakan bahwasanksi perpajakan berpengaruh positif terhadap kepatuhan wajib pajak.Dapat disimpulkanbahwa apabila Dirjen Pajak menjalankan sanksi pajak dengan tegas dan jelas, sehingga dapatmeningkatkan kepatuhan wajib pajak (Prihastini, 2019). Hal ini dikarenakan dengan adanyapengenaan sanksi pajak akan dapat meningkatkan kesadaran hak dan kewajiban wajib pajakserta meningkatkan kepatuhan wajib pajak dalam kewajiban perpajakannya.

\section{Pengetahuan Pajak Terhadap Kepatuhan Pajak}

Menurut Oladipupo dan Obazee (2016) dalam penelitian Gandi Wahyu (2020) menyatakan bahwa pengetahuan pajak mengandung informasi pajak yang dapat digunakan oleh wajib pajak sebagai dasar untuk bertindak, membuat keputusan, dan untuk mengambil arahan atau strategi tertentu sehubungan dengan pemenuhan hak dan kewajiban perpajakan mereka. Apabila wajib pajak tidak memiliki kemampuan yang baik maka kemungkinan besar wajib pajak tidak menyadari pentingnya memenuhi hak dan kewajiban perpajakan. Pengetahuan perpajakan memberikan informasi yang sangat berguna bagi wajib pajak untuk menghitung, membayar dan melaporkan jumlah pajak yang menjadi kewajibannya (Khasanah, 2014)dalam penelitian Gandi Wahyu (2020). Pengetahuan wajib pajak merupakan faktor penting dalam meningkatkan kepatuhan wajib pajak, apabila wajib pajak mengetahui secara baik mengenai ketentuan perpajakan yang berlaku, maka wajib pajak dapat secara sukarela memenuhi kewajiban pajaknya (Zuhdi et al., 2015).Beberapa penelitian 
sebelumnya seperti Palil, M. R., et.al (2013) dan Zuhdi et.al. (2015) menunjukkan bahwa semakin tinggi tingkat pengetahuan wajib pajak mengenai peraturan perapajakan maka akan semakin tinggi tingkat kepatuhan pajaknya.

\section{SIMPULAN}

Berdasarkan hasil dan pembahasan yang telahjabarkan, maka dapat ditarik kesimpulan hasil analisis penelitian ini menyatakan bahwa sanksi perpajakan berpengaruh positif terhadap kepatuhan wajib pajak dapat meningkatkan kedisiplinan terhadap kepatuhan wajib pajak orang pribadi serta adanya upaya untuk meningkatkan pemahaman masyarakat tersebut terhadap pentingnya pajak bagi pembangunan negara.Beberapa penelitian sebelumnya seperti Palil, M. R., et.al (2013) dan Zuhdi et.al. (2015) menunjukkan bahwa semakin tinggi tingkat pengetahuan wajib pajak mengenai peraturan perapajakan maka akan semakin tinggi tingkat kepatuhan pajaknya.

\section{UCAPAN TERIMAKASIH}

Ucapan terimakasih ditujukan kepada Program Studi Perbankan Syariah, Fakultas Ekonomi Bisnis Islam tempat Peneliti mengabdi, Terimakasih juga kepada Tim Jurnal Utility STKIP Nurul Huda.

\section{REFERENSI}

Purnamasary, Popy dan Rachmawati Meita Oktaviani. (2020). "Kesadaran Membayar Pajak

Memediasi Hubungan Pengetahuan Perpajakan Terhadap Kemauan Membayar Pajak".

Jurnal Akuntansi dan Pajak.DOI: http://dx.doi.org/10.29040/jap.v21i1.1088

Citra Utami, Aprillia. (2020). "Pengaruh Kesadaran Wajib Pajak dan Sanksi Perpajakan Terhadap Kepatuhan Wajib Pajak Orang Pribadi"

Dumandi, Nurul Imanul Qur'an, dan Indah Dewi Mulyani. (2020). "Pengaruh Kesadaran Wajib Pajak, Pelayanan Fiskus Dan Sanksi Pajak Terhadap Kepatuhan Wajib Pajak Badan Usaha".

Journal ofAccounting and Finance (JACFIN).Volume 1, No. 1, Agustus 2020, pp.1-7

Laksmi Gunawan, Dewinta. (2017). "Evaluasi Kepatuhan Wajib Pajak dalam Pembayaran Pajak Hiburan di Kota Malang".

Qibtisari Nugroho, Venichio (2020). "Pengaruh Sosialisasi Perpajakan, Kesadaran Wajib Pajak, dan Sanksi Perpajakan Terhadap Kepatuhan Pajak" Jurnal IImu dan Riset Akuntansi. Volume 9, Nomor 1, Januari 2020

Wahyu Maulana Zulma, Gandy. (2020)."Pengaruh Pengetahuan Wajib Pajak, Administrasi Pajak, Tarif Pajak dan Sanksi Perpajakan terhadap Kepatuhan 


\section{Pengaruh Sanksi Pajak Serta Pengetahuan Masyarakat Tentang Pajak Terhadap Kepatuhan Membayar Wajib Pajak}

Pajak Pada Pelaku Usaha UMKM di Indonesia". Ekonomis: Journal of Economics and Business,4(2), September 2020, 288-294

https://www.kemenkeu.go.id/apbn2020diakses pada tanggal 26 Oktober 2020 pukul 21:02 WIB

Remali, A.M., Satar, A.N., Mamad, F.N.A., Abidin, N.F.T., \& Zainudin, S.Z. (2018). "Tax Knowledge, Tax Penalty and Tax Rate on Tax Compliance among Small Medium Enterprise in Selangor".

Global Business and Management Research: An International Journal. Vol. 10, No. 3.

Palil, M. R., Akir, M. R. and Ahmad, W. F. B. A. (2013). The perception of tax payers on tax knowledge and tax education with level of tax compliance: A study the influences of religiosity. ASEAN Journal of Economics, Management and P, 1(1).

https://pajak.go.id/id/pajak diakses pada tanggal 28 Oktober 2020 Pukul 16:42 UNNES. 